(C) 2020, The Authors. Published by Elsevier Inc. and Fass Inc. on behalf of the American Dairy Science Association ${ }^{\circledR}$. This is an open access article under the CC BY-NC-ND license (http://creativecommons.org/licenses/by-nc-nd/4.0/).

\title{
Invited review: Maintaining and growing fluid milk consumption by children in school lunch programs in the United States
}

\author{
Lauren R. Sipple, ${ }^{1} \odot$ David M. Barbano, ${ }^{2} \odot$ and MaryAnne Drake ${ }^{1 *}$ (이 \\ ${ }^{1}$ Department of Food, Bioprocessing, and Nutrition Sciences, Southeast Dairy Foods Research Center, North Carolina State University, \\ Raleigh 27695 \\ ${ }^{2}$ Department of Food Science, Northeast Dairy Foods Research Center, Cornell University, Ithaca, NY 14853
}

\begin{abstract}
Fluid milk consumption among children has declined for decades. Adequate consumption of milk and dairy products, especially during childhood, has beneficial health outcomes for growth, development, and reduced risk of osteoporosis, hypertension, obesity, and cancer during adulthood. Satisfaction with milk flavor, perceived health benefits derived from milk, and habit are primary drivers of lifelong milk consumption. Child preferences and attitudes for milk may differ from those of adults, and as such, understanding and fulfilling the needs of children is crucial to reverse the decline in milk consumption. School meal programs make fluid milk accessible to millions of children each day; however, regulations and school lunch procurement systems in the United States sometimes make it difficult to provide novel or value-added milk products in these programs. Total consumption of all milk types in US schools declined by $14.2 \%$ from 2008 to 2017 , and the percentage of children participating in the school lunch program has also declined. This decline has also been driven by declining average daily participation in the school meal program and may also reflect children's dissatisfaction with the sensory characteristics and the form of milk offered in schools. The change in form of milk offered in schools to lower fat and lower added sugar content in the United States has been driven by government-mandated school lunch calorie and fat requirements. This review describes the current milk consumption trends among children; the structure and basic requirements of the school lunch program in total and for milk; and the intrinsic, extrinsic, and environmental factors that influence child perception, preference, and consumption of fluid milk in the US school system.

Key words: kids, school lunch, fluid milk
\end{abstract}

\footnotetext{
Received January 17, 2020.

Accepted April 13, 2020.

*Corresponding author: mdrake@ncsu.edu
}

\section{INTRODUCTION}

Dairy consumption during childhood and adolescence has lasting impacts on lifelong health status (Huth et al., 2006). A primary predictor of lifetime milk consumption is habit developed during childhood (McCarthy et al., 2017a); thus, ensuring adequate consumption during primary and secondary education years is of the utmost importance. Evaluating child perceptions and preferences for fluid milk is necessary because their needs and wants differ from those of adults (Guinard, 2000), but also because correlations have been established between food preferences in early childhood and those in later childhood (Skinner et al., 2002), adolescence (Nu et al., 1996), and young adulthood (Nicklaus et al., 2004). Repeated exposure to particular foods is also a key driver of preference that has been demonstrated in a variety of studies (Wardle et al., 2003; Anzman-Frasca et al., 2012; Ventura and Worobey, 2013).

The aim of this review is to describe the past and current regulations that influence the milk served in school lunch programs, as well as current milk consumption trends and health outcomes for fluid milk consumption by children in the school lunch program. Additionally, a variety of intrinsic, extrinsic, and environmental attributes affecting child consumption and preferences of fluid milk will be explored.

\section{MILK IN SCHOOL MEAL PROGRAMS}

Federal assistance programs that provide reimbursement for the cost of lunch in schools have been in place since the 1940s (Gunderson, 2017). Over the years, these programs became a part of the National School Lunch Program (NSLP; USDA, 2019a) and the School Breakfast Program (SBP; USDA, 2019b). These programs serve nearly 30 million lunches and 15 million breakfasts to students every day. Schools, child care institutions, and eligible camps that do not participate in these programs can participate in the Special Milk Program (SMP; USDA, 2019c). The program, 
titled "The Richard B. Russell National School Lunch Act," was revised in 2019 (Richard B. Russell National School Lunch Act, 2019). Schools that participate in the NSLP, SBP, or SMP can receive cash subsidies for reimbursable meals or milk pints served, provided that nutrition standards codified in the Code of Federal Regulations [CFR Parts 210 (i.e., nutrition standards and menu planning approaches for lunches and requirements for afterschool snacks) and 220 (i.e., SBP: nutrition standards and menu planning approaches for breakfasts] are met. The reimbursement is intended to ensure adequate food intake and nutrition for children (Logan et al., 2019). To meet nutritional standards, schools participating in the NSLP and SBP are required to offer 1 cup of milk per day to students as a part of their breakfast and lunch. All milk must be pasteurized and fortified with vitamins $\mathrm{A}$ and $\mathrm{D}$, and students must have at least two options of milk (one must be unflavored), which can be fat-free or low-fat varieties of flavored or unflavored milk (Code of Federal Regulations, 2019a). Non-dairy milk options are only offered to students with special medical or dietary needs, and the alternative must provide a nutritional profile comparable to that of dairy milk as defined in the meal requirement for lunches (Code of Federal Regulations, 2019a). From 2012 to 2017, USDA regulations required that only fat-free flavored milk could be offered through these programs (Federal Register, 2017). In summary, in 2008, the regulations required a reduction in the fat content of white milk served in schools, with the elimination of $2 \%$ fat white milk from the program in 2012. The fat content of flavored milks was lowered to be required to be fat-free in 2012 . These restrictions to achieve lower calories, specifically lower calories from fat, in the school lunch and a decrease in student participation in the school lunch program coincide with a $14.2 \%$ decrease in all milk sold in US schools from 1.835 million kilograms in 2008 to 1.573 million kilograms in 2017 (MilkPEP, 2017). For the year 2017, about 60, 32, and $8 \%$ of milk sales were chocolate, white, and other flavored milks, respectively, and these numbers have been about the same for many years (MilkPEP, 2017). The largest decline was in consumption of chocolate milk. The offering of chocolate milk is sometimes prohibited for all students in some school districts because of local school board decisions that will be discussed later in this review. White milk with $2 \%$ fat and $1 \%$ low-fat flavored milk were eliminated from the milk offered in the school lunch program due to concerns regarding saturated fat, sugar, and calorie content. In addition, the amount of added sugar in flavored milk was decreased from $16.7 \mathrm{~g} / 240-\mathrm{mL}$ serving in 2006 to $7.5 \mathrm{~g} / 240-\mathrm{mL}$ serving in 2017 (MilkPEP, 2017). The decline in chocolate milk consumption suggests that these changes in fat and sugar content decreased children's satisfaction with the sensory properties of school milk. However, the "Flexibilities for Milk, Whole Grains, and Sodium Requirements" interim rule put in place in 2017 (Federal Register, 2017) granted Child Nutrition Program operators the flexibility to again offer flavored low-fat (1\%) milk. The final rule was fully implemented to allow 1\% fat flavored milk as of the 2019-2020 school year (Federal Register, 2018). Based on flavored low-fat milk offering and purchase data before 2012, the change in 2018 to allow flavored milk to contain 1\% fat may recover some school milk consumption that was lost in the United States during the period from 2012 to 2017. The ruling was meant to address concerns of Child Nutrition Program operators and industry partners regarding declining milk consumption in NSLP participants in elementary, middle, and high school (Federal Register, 2018). The decision was also based on recent studies that have found that removing flavored milk from schools resulted in significant declines in milk consumption (Quann and Adams, 2013).

The NSLP, SBP, and SMP provide billions of half pints of milk to school children every year. Participants in NSLP and SBP consume more milk than nonparticipants (Condon et al., 2009). It is worth noting that although these programs give children access to milk, over one-quarter of the milk served in the NSLP and almost half of the milk served in the SBP is wasted - that is, discarded and not consumed - which has undesirable nutritional, economic, and environmental implications (Blondin et al., 2017).

\section{NUTRITION REQUIREMENTS FOR THE SCHOOL LUNCH PROGRAM}

The official details of the school lunch program in the United States are described in the Richard B. Russell National School Lunch Act, Chapter 281 of the 79th Congress, Approved June 4, 1946, 60 Stat. 230, As Amended Through P.L. 116-6, Enacted February 15, 2019 (Richard B. Russell National School Lunch Act. 2019). The details of nutrient requirements and composition for meals are given in the Code of Federal Regulations (2019a). The target nutrient values are broken out by kindergarten through fifth grade, sixth through eighth grade, and ninth through twelfth grade because public schools in the United States tend to be organized in this fashion, and cafeteria programs in school districts tend to be grouped in this way. The composition definitions and requirements are written simply and broadly to allow flexibility in menu planning. The mean calorie and sodium content of the school lunch for a week in a school district needs to be within specific ranges for each of the previously men- 
tioned groups. Therefore, school districts need to work toward achieving these targets for calories and sodium content per meal for all grades averaged over the course of a week; saturated fat also needs to be $<10 \%$ of total calories and the amount of fat from trans fats needs to be zero.

In addition, there are food group requirements for the lunch. Food group requirements for fluid milk are 1 serving $(240 \mathrm{~mL})$ of skim or $1 \%$ fat milk that may be flavored or unflavored. A typical 240-mL serving of skim milk contains between 80 and 90 calories and that of $1 \%$ fat milk contains from 100 to 110 calories. Flavored milks will have a higher calorie content per serving because some amount of sugar is typically added to flavored milks. At least 2 types of milk need to be provided. Lactose-reduced or lactose-free milk may be provided to meet special needs. For those who have a documented reason not to drink milk, a nondairy beverage (such as soy milk) that meets the USDA nutrition standards for milk substitutes milk alternatives may be offered. The final rule milk substitute standards for the US school lunch program were published in the Federal Register (2008) and define that nondairy fluid milk substitutes must be fortified with calcium, protein, vitamins $\mathrm{A}$ and $\mathrm{D}$, riboflavin, vitamin $\mathrm{B}_{12}$, magnesium, phosphorus, and potassium to the levels found in whole milk (3.25\% milkfat). If a nondairy milk substitute does not meet both federal and state standards, it cannot be served as part of a reimbursable meal.

An overview of the school milk meal program is provided in School Nutrition and Meal Cost Study, Final Report volume 1: School Meal Program Operations and School Nutrition Environments (Forrestal et al., 2019). The NSLP and SBP form the cornerstone of the nation's nutrition safety net for low-income children. These programs, which are administered by the USDA Food and Nutrition Service (FNS), provide 30 million lunches and 15 million breakfasts to children each school day that are subsidized by the US federal government (Forrestal et al., 2019). For the school districts that follow the above standards, they may be eligible for the USDA reimbursable meal program, as described in the Federal Register (2019). For the period from July 1, 2019, through June 30, 2020, the rate of reimbursement for a half-pint of milk served to a nonneedy child in a school or institution that participates in the SMP was 21.50 cents, reflecting an increase of 1 cent from the 2018-2019 school year level. Several other payment details, exceptions, and criteria are provided and the reimbursement rate is adjusted annually based the change in the Producer Price Index for Fluid Milk Products. A detailed summary of the nutritional characteristics of school meals is provided in the School
Nutrition and Meal Cost Study, Final Report volume 2: Nutritional Characteristics of School Meals (Gearan et al., 2019).

A detailed summary of the school meal costs and revenues is provided in the School Nutrition and Meal Cost Study, Final Report volume 3: School Meal Costs and Revenues (Logan et al., 2019). Not all school districts nationally participate in the school lunch reimbursement program, and the level of reimbursement varies from district to district. Using the meal as the unit of analysis, the mean reported cost of the average lunch was $\$ 3.66$, substantially more than the mean federal subsidy of $\$ 3.32$ per free lunch (Logan et al., 2019). A detailed summary of the school participation and outcomes is provided in the School Nutrition and Meal Cost Study, Final Report volume 4: Student Participation, Satisfaction, Plate Waste, and Dietary Intakes (Fox et al., 2019).

Improving liking of milk by students in a school lunch program while delivering nutritional benefit and minimizing waste is a challenge. As will be seen in the next section of our review, milk consumption by school-age children has declined, and satisfaction with milk in the face of constantly increasing competition from other beverages within and outside schools is a challenge for the dairy industry. Modernizing milk as a beverage with delivery of added nutrition and convenience benefits in the context of today's lifestyle could be important for future success. The institutional and economic environment of the school system and sensory preference of children will need to be considered seriously by the dairy industry to improve milk consumption.

\section{MILK CONSUMPTION TRENDS}

The overall consumption of milk by children and adolescents ages 2 to 18 yr has decreased significantly since the 1970s in terms of the proportion of children consuming milk, the number of servings consumed per day, and the proportion of each serving size (Dror and Allen, 2014). This trend has also been observed in children participating in school lunch programs, with only $66 \%$ of NSLP participants consuming milk in the 2014-2015 school year compared with $75 \%$ during the 2004-2005 school year (Fox et al., 2019).

In both children and adolescents for total milk consumption (in and out of school), plain milk consumed as a beverage is the largest contributor to dairy and milk consumption (Sebastian et al., 2010; Green et al., 2015). In children ages 2 to $11 \mathrm{yr}$, flavored milk is the second largest contributor followed by plain milk added to cereal (Sebastian et al., 2010). This trend is reversed in adolescents ages 12 to $19 \mathrm{yr}$; plain milk added to ce- 
real is the second largest contributor to milk consumption followed by flavored milk as a beverage (Sebastian et al., 2010). Overall consumption of plain milk with at least $1 \%$ fat has decreased significantly, whereas consumption of flavored milk with added sugar (regardless of milkfat content) has increased significantly since the National Health and Nutrition Examination Surveys (NHANES) in 1989-1991 (Dror and Allen, 2014). Only $20 \%$ of children were found to regularly consume lowfat and skim milk, whereas 45.4 and $32.4 \%$ reported drinking milk containing 2 and $3.3 \%$ fat outside of school, respectively (Kit et al., 2011).

\section{MILK CONSUMPTION AND CHILDREN'S HEALTH}

The importance of milk in the diets of children cannot be overstated, which makes the recent decline of milk consumption a concern. The Dietary Guidelines for Americans (2015-2020) recommends that children 4 to 8 yr old consume 2.5 cup-equivalents of fat-free and low-fat dairy; the recommendation for adolescents aged 9 to $18 \mathrm{yr}$ is 3 cup-equivalents per day (USDHHSUSDA, 2015). Unfortunately, consumption of dairy products falls short of these recommendations for children 4 yr of age and older (Quann and Adams, 2013). Fluid milk is the number one single-food contributor to the intake of calcium, potassium, phosphorus, and vitamin $\mathrm{D}$ in children older than 2 yr of age (Rafferty and Heaney, 2008). In the United States, an estimated $72 \%$ of dietary calcium comes from dairy products such as milk, yogurt, and cheese, as well as other foods containing dairy products (Ross et al., 2011). The average recommended dietary allowance (RDA) or adequate intake of calcium is about $900 \mathrm{mg} / \mathrm{d}$ (800 to $1,000 \mathrm{mg}$, depending on the country) for adults, rising to 1,200 $\mathrm{mg} / \mathrm{d}$ for adolescents and the elderly (Institute of Medicine, 2010). Milk provides large amounts of calcium and phosphorus and components such as lactose and casein phosphopeptides, which may enhance calcium absorption and mineral retention (Guéguen and Pointillart, 2000).

The vitamin D and calcium content of milk and dairy products positively influences peak bone mass, and therefore skeletal integrity and susceptibility to bone loss later in life (Sandler et al., 1985). This makes milk consumption during childhood and adolescents crucial to bone health (Weaver, 2010). Black et al. (2002) found that children who avoided drinking milk were more likely to have inadequate calcium intake and poor bone health, including lower bone area and bone mineral density, compared with children who consumed milk. Children who consumed $\geq 2$ servings of dairy per day had higher bone mass, area, and density than children who consumed less (Kalkwarf et al., 2003; Moore et al., 2008). Although dairy consumption throughout all life stages is also necessary for maintenance of bone mass density, formation of dairy consumption habits in early childhood is important because this may influence consumption later in life (Kelder et al., 1994; Eysteinsdottir et al., 2014). In addition to its impact on bone health, milk consumption has been associated with a lower risk of cardiovascular disease, hypertension, colon cancer, and type 2 diabetes (Huth et al., 2006; Weaver, 2010; World Cancer Research Fund International, 2018). Milk components including calcium and whey protein may also play a role in weight control, although further research is warranted because of inconsistent findings regarding dairy intake and weight, particularly for children and adolescents (Huth et al., 2006; Abargouei et al., 2012; Rautiainen et al., 2016; Dougkas et al., 2019).

\section{FACTORS AFFECTING CHILDREN'S PERCEPTION AND CONSUMPTION OF MILK}

\section{Intrinsic Factors}

Milkfat Content. There are several reports that children prefer foods that are higher in fat content (Johnson et al., 1991; Kern et al., 1993; Kildegaard et al., 2011). There is little literature available on the effect of milkfat content on child liking or consumption of milk. However, it is well established that varying milkfat content affects sensory properties of fluid milk including color, mouthfeel attributes (e.g., thickness, creaminess, residual mouthfilm), aroma, and flavor (Phillips et al., 1995; Phillips and Barbano, 1997; Frøst et al., 2001; Chojnicka-Paszun et al., 2012; McCarthy et al., 2017b). Kling et al. (2016) determined liking and intake of low-fat (1\% fat) versus whole (3.25\% fat) milk for children (ages 3 to $6 \mathrm{yr}$ ). The study reported that children's $(n=107)$ liking and preference scores were similar for both low-fat and whole milk. Kling et al. (2016) served the different milk types to children in a clear plastic container with their lunch. The meal was constant in composition and portion size for all children and treatments. Fat content did not significantly affect the amount of milk that children $(\mathrm{n}=125)$ consumed with a meal. Studies have suggested that young females may have an aversion to milk due to perceived caloric or fat content (Horwath et al., 1995), but other studies have reported that dislike of milk or dislike of milk aftertaste was a factor in milk dislike by young females (Porubcan and Vickers, 2005). In contrast, Green et al. (2015) reported no differences in milk consumption between children 9 to $11 \mathrm{yr}$ old and adolescents aged 12 to 18 yr, although males consumed more milk than females. 
Many more studies have been performed regarding milkfat preference and consumption in adults; in contrast to studies in children, these studies have found that fat level influences milk liking. Several studies have found that preferences in milkfat are associated with the type of milk that is typically consumed by an individual (Tuorila, 1987; Bakke et al., 2016; McCarthy et al., 2017b). For instance, McCarthy et al. (2017b) found that consumers preferred milk that had a higher fat content than what they usually consumed, citing that it had better appearance, flavor, thickness, or creaminess. However, the study also found that although skim and low-fat milk drinkers preferred $2 \%$ milk over skim, they did not prefer milk that was any higher in fat than $2 \%$, as it was perceived as too thick, fatty, and heavy. This result suggests that consumers prefer milk that has similar sensory characteristics to milk they have consumed for a long period (McCarthy et al., 2017b). The effect of milkfat percent typically consumed might not be as great in children, especially those who are younger, as such habits and preferences may not be well established yet (Ventura and Worobey, 2013). Robb et al. (2007) found that consumption of low-fat milk was positively associated with age, likely due to greater emphasis on reducing total dietary fat consumption.

Flavored Milk. The majority of children prefer flavored milk over plain milk as it is perceived as more palatable than plain milk (De Pelsmaeker et al., 2013; Fayet-Moore, 2016), and as such, flavored milk is positively associated with a higher overall milk intake (Johnson et al., 2002; Nicklas et al., 2017). Thompson et al. (2007) found that chocolate milk was the most popular flavored milk among children, while other commonly consumed flavored milks included strawberry and vanilla. The primary argument for serving flavored milk in schools is that removal of flavored milk from school lunch programs results in lower overall milk consumption (Patterson and Saidel, 2009; Quann and Adams, 2013; Henry et al., 2015). Quann and Adams (2013) observed that when flavored milk was removed from elementary schools, not only was less milk purchased but more of the milk that was purchased was thrown away; the results of Quann and Adams (2013) are consistent with the decrease in chocolate milk consumption reported by MilkPEP 2017. In a study with children in grades 1 through 8, Henry et al. (2015) also found that overall more students chose to drink milk when both chocolate and plain were available. Although milk consumption was the lowest when only plain milk was offered, the percentage of students consuming plain milk rose from 3 to $14 \%$ when both flavored and plain milks were offered. However, a grade effect was observed, with students in grades 5 through 8 consuming milk less often after chocolate milk removal than children in grades 1 through 4 .

Davis et al. (2017) found that the mean amount of milk consumed among kindergarten to second grade students was $59.5 \mathrm{~g}(2.1 \mathrm{oz}$.) in students who did not consume chocolate milk and $68 \mathrm{~g}$ (2.4 oz.) in those who did consume chocolate milk; the average amount of milk wasted by these 2 groups was between 3 and $5 \mathrm{oz}$. of milk per meal. Because of the large amount of milk wasted, the authors noted the importance of looking at individual level beverage and plate waste data in subsequent studies assessing changes in student consumption and nutritional intake from school-provided meals. Davis et al. (2017) also found that milk consumption overall was only $8.5 \mathrm{~g}(0.3 \mathrm{oz}$.) less for nonchocolate milk drinkers and $11.35 \mathrm{~g}$ (0.4 oz.) less for chocolate milk drinkers when chocolate milk was removed as a beverage option from school lunch. This result may suggest that younger students are more apt to switch to plain milk when flavored milk is no longer offered, but that this effect does not occur with older children whose nutritional needs continue to benefit from fluid milk consumption.

Children who consume flavored milk tend to have lower intake of soft drinks and fruit juice (Johnson et al., 2002) and should have higher intake of protein, calcium, and essential amino acids from milk compared with non-consumers of milk. This makes flavored milk a very important component of nutrient intake in children and adolescents. Flavored milk has the same major nutrient content (e.g., protein, calcium, essential amino acids) as unflavored milk. Because of its effect on increased overall consumption, however, flavored milk has the potential to increase the intake of several essential nutrients, including calcium, phosphorus, potassium, vitamin $\mathrm{D}$, and vitamin A (Johnson et al., 2002; Murphy et al., 2008; Nicklas et al., 2013; Henry et al., 2015). As previously discussed, consumption of these nutrients during childhood and adolescence is crucial to lifelong health.

The consumption of flavored milk by children has been met with health concerns, particularly related to obesity and dental caries because of the sugar added to flavored milks. The American Dental Association (2000) cautioned that unrestricted consumption of beverages containing fermentable sugars, such as milk, can contribute to tooth decay. However, Murphy et al. (2008) reported that adjusted intakes of added sugars were comparable for children above the age of $5 \mathrm{yr}$ regardless of whether the children consumed flavored or unflavored milk. A study by Dunning and Hodge (1971) found that drinking chocolate milk with added sugar was not significantly associated with incidence of dental caries compared with drinking plain milk. Conflicting 
data exist on the effect of drinking flavored milk instead of plain milk on adiposity and energy intake. Although some studies say that drinking flavored milk over plain milk is not related to energy intake in children over the age of $5 \mathrm{yr}$ or to the weight status of children (Murphy et al., 2008; Nicklas et al., 2013), other studies suggest that energy intake may be increased by flavored milk consumption (Noel et al., 2013; Patel et al., 2018). Therefore, further research is needed to investigate the relationship between flavored milk consumption and body composition.

The Committee on Nutrition Standards for National School Lunch and Breakfast Programs, Food and Nutrition Board of the Institute of Medicine (IOM) agreed in their report (Stallings et al., 2010) that the fat content of the fluid milk offered be limited to $1 \%$ (the fat content of low-fat milk). The IOM committee acknowledged that the Dietary Guidelines for Americans (USDHHS-USDA, 2015) advises the consumption of foods and beverages with little added sugar. The committee considered advantages and disadvantages of retaining flavored milk as a milk option. The IOM committee agreed to retain flavored fat-free milk. Flavored milks have been and continue to be the predominant milk choice at school (MilkPEP, 2017). The committee was concerned that eliminating all flavored milk would result in a substantial decrease in milk intake (as indicated by Murphy et al., 2008), especially if plain reduced-fat ( $2 \%$ milk fat) and whole milk are eliminated from the menu. The maximum calorie level for school meals places a limit on the amount of added sugars (and saturated fats) that may be included in the foods offered; thus, the amount of added sugar and fat level in milk would, in practicality, be limited by the maximum total calories in the lunch.

Sweeteners. The USDA does not have limits on added sugar or total carbohydrates for flavored milk served in school meal programs (Code of Federal Regulations. 2019a). Instead, the maximum calorie level per meal is assumed to limit inclusion of foods and beverages with high levels of added sugar, forcing schools to opt for low-fat unflavored milk or flavored milks containing less sugar. Because of health concerns associated with added sugar and calorie restrictions in school lunch programs, sugar reduction in flavored milk for these school lunch programs is of great interest. Additionally, parents prefer flavored milk with reduced sugar for their children over milk with no sugar added or regular sugar content (Kim et al., 2013; Li et al., 2014). In regards to sweetener type, parents prefer sucrose or natural nonnutritive sweeteners over highfructose corn syrup or artificial nonnutritive sweeteners (Li et al., 2014). The amount of added sugar in flavored milk in the school lunch program was decreased from $16.7 \mathrm{~g} / 240-\mathrm{g}$ serving in 2006 to $7.5 \mathrm{~g} / 240-\mathrm{g}$ serving in 2017 (MilkPEP 2017).

A study by Li et al. (2015a) investigated the effect of direct sucrose reduction on children's (ages 5 to $13 \mathrm{yr}$ ) acceptance of chocolate skim milk. Although the study confirmed that children of all ages preferred the milk with the highest sucrose concentration, the authors also reported that sucrose reductions up to about $30 \%$ (from 16.8 to $11.7 \mathrm{~g}$ of added sucrose) were accepted by children. Similar results have been reported for adults (Li et al., 2015a; Oliveira et al., 2016). Sucrose reduction beyond about 30\% had linear negative effects on overall liking, sweetness liking, and chocolate taste liking scores for all ages of children. Likewise, Buczkowski et al. (2018) found that among children from 4 to 10 yr in the United Kingdom, there was no difference in liking of chocolate milk with $30 \%$ sucrose reduction compared with a control (added sugar level in the control was not reported), whereas a $40 \%$ reduction of sucrose resulted in significantly lower liking scores. Henry et al. (2016) studied the effect of replacing $1 \%$ fat chocolate milk containing $25 \mathrm{~g}$ of added sugar with a $25 \%$ reduced sugar (19 $\mathrm{g}$ of added sugar) formulation containing no artificial sweeteners on student (grades 1 through 8) milk consumption during lunch in Canada. School children preferred chocolate milk over plain milk even when a reduced-sugar formula was offered; however, switching to reduced-sugar chocolate milk led to a decrease in the number of students choosing milk. Longer-duration studies are required to determine whether students would purchase reduced-sugar chocolate milk at the same rate as they would purchase regular chocolate milk.

The use of nonnutritive sweeteners is an option that has the potential to reduce the sugar content of flavored milk while maintaining the sweetness and acceptance of sugar-reduced products. Alternative sweeteners could be used to reduce the added sugar content of flavored milk and lower the caloric content of milk without compromising milk consumption. Use of alternative sweeteners would reduce the risk of dental caries, as these nonnutritive sweeteners cannot be metabolized by oral microflora (Gupta et al., 2013). Li et al. (2015b) reported that parents placed the most importance on sweetener type when purchasing chocolate milk for their children. Parents were more likely to be accepting of natural nonnutritive or noncaloric sweeteners for sugar reduction as these are preferred over milk sweetened with sucrose or with artificial sweeteners (i.e., synthesized sweeteners such as aspartame, acesulfame, and saccharin; Li et al., 2015b). Lack of acceptance of artificial sweeteners by parents may be due to a lack of 
parental recognition of artificial sweeteners, the belief that these sweeteners are not safe for their child to consume, or the current general emphasis on a natural label and natural sweeteners (Sylvetsky et al., 2014; Parker et al., 2018; Smith et al., 2019). Sugar, sugar alternatives, and approaches to sugar reduction in dairy foods have been reviewed (McCain et al., 2018).

Few studies have examined child acceptance of these alternative sweeteners in flavored milk specifically. $\mathrm{Li}$ et al. (2015b) produced chocolate skim milks including a sucrose control at $12.3 \mathrm{~g}$ added sucrose per $240-\mathrm{mL}$ serving as well as 25,50,75, and $100 \%$ reduced sucrose milks that contained stevia leaf or monk fruit extracts added at concentrations to obtain the same sweetness in these milks as in the sucrose control. The $12 \mathrm{~g}$ of added sugar was in addition to the $12 \mathrm{~g}$ of lactose in a 240-mL serving of milk. The reduced-sugar formulations selected for acceptance testing with children, in addition to a sucrose control, were $25 \%$ reduced-sugar milk + monk fruit extract and $25 \%$ reduced-sugar milk + stevia extract. Li et al. (2015b) reported that there were no differences in overall liking, sweetness liking, or chocolate flavor liking for the sucrose control, reducedsugar/monk fruit, or reduced-sugar/stevia sweetened flavored milks for children $(\mathrm{n}=110)$ ages 8 to $13 \mathrm{yr}$. Another study (Castillo et al., 2005) with Peruvian children examined the use of xylitol and sorbitol to sweeten plain (unflavored) milk. In that study, children $(\mathrm{n}=75)$ preferred sweetened milk over unsweetened milk and preferred milk sweetened with xylitol over milk sweetened with sorbitol. Finally, a study with children ages 1.5 to $5 \mathrm{yr}$ comparing consumption of aspartame-sweetened or sucrose-sweetened chocolate milk found that intake of these milks was not significantly different, and found that overall energy (calories) consumed when the milks were served at lunch was less when children consumed the aspartame-sweetened milk versus the sucrose-sweetened milk (Wilson, 2000).

Another method for sweetening milk that could allow for sugar reduction is lactose hydrolysis with $\beta$-galactosidase (lactase). Although its acceptance has not been explicitly studied with children, $\mathrm{Li}$ et al. (2015b) found that young adults did not have a significant difference in overall liking of chocolate milk sweetened with sucrose (11.7 g of sucrose/240-mL serving) and lactose-hydrolyzed chocolate milk with 10 $\mathrm{g}$ of added hydrolyzed lactose $/ \mathrm{mL}$. However, the authors found that the amount of added lactose needed to achieve sweetness in a lactose-hydrolyzed milk (i.e., the background $12 \mathrm{~g}$ of lactose and the $10 \mathrm{~g}$ of added lactose for a total of $22 \mathrm{~g}$ of hydrolyzed lactose) was comparable in total carbohydrates to that of regular sucrose-sweetened chocolate milk (12 g of lactose plus
$11.7 \mathrm{~g}$ of sucrose) and was too high for the lactose-hydrolyzed milk to be considered "reduced-calorie." This suggests that lactose hydrolysis may not be a viable option for sweetening chocolate milk (and achieving a calorie reduction) due to the inherent bitterness of cocoa; however, it may be more practical for naturally sweetening other flavored milks, such as vanilla (Li et al., 2015b). A combined approach with lactose hydrolysis and another sugar reduction approach such as a natural nonnutritive sweetener may be a viable alternative for sugar reduction in chocolate milk. Membrane filtration, which is discussed later, is another option for lactose reduction although, unlike lactose hydrolysis, this method does not increase sweetness of the milk (McCain et al., 2018).

Heat Treatment. Milk is heat treated at a variety of different temperatures to maintain product quality and safety, and the processing time and temperature can have significant impacts on milk sensory characteristics. These differences in sensory properties have been shown to affect child acceptance of fluid milk products (Chen et al., 1996; Chapman and Boor, 2001; Lee et al., 2017). The times and temperatures for heat treatment of milk are specified in the Code of Federal Regulations (2019b). In conventional pasteurization, fluid milk must be heated to $72^{\circ} \mathrm{C}$ for $15 \mathrm{~s}$. Ultrapasteurization (UP) is defined as heating to at least $138^{\circ} \mathrm{C}$ for $2 \mathrm{~s}$. Applying UP with aseptic filling produces a product that does not have to be refrigerated and is deemed aseptic, shelf-stable, or UHT processed milk. Utilizing UHT and UP approaches significantly extends the shelf life of the milk beyond that of conventionally pasteurized milk. The use of an extended-shelf-life or shelf-stable milk could reduce milk waste in school meal programs (Beckerman et al., 2019) and reduce distribution costs by permitting less-frequent nonrefrigerated delivery with reduced storage and refrigeration costs, which are significant contributors to the total cost of milk in schools. This proposed option will only work if children like the sensory properties of the aseptic milk, which has not, to our knowledge, been demonstrated in peer-reviewed research.

Chapman and Boor (2001) reported that children from 6 to 11 yr significantly preferred $2 \%$ milkfat HTST-pasteurized milk to UHT milk, and that UHT milk was preferred over UP milk. Similarly, Chen et al. (1996) found a preference for 2\% HTST-pasteurized milk over UHT milk in children ages 3 to $5 \mathrm{yr}$. Lee et al. (2017) found that children had a significant preference for HTST milk over UP milk, regardless of the fat content or whether it was produced by direct steam injection or indirect heating. Both UHT and UP milks have significantly higher cooked flavor than HTST milk 
due to the release of volatile sulfur compounds from denaturation of whey proteins during heat treatment (Al-Attabi et al., 2009, 2014; Lee et al., 2017; Jo et al., 2019). Cooked flavor and increased astringency (also identified in UP milk) are perceived as off-flavors that are disliked by most consumers and commonly limit consumer acceptance of UHT and UP milk (Liem et al., 2016; Lee et al., 2017; Jo et al., 2019). The preference for HTST milk in children may also be due to familiarity because HTST milk is commonly served in the home, daycare, or school. Children prefer foods that are familiar (Ventura and Worobey, 2013).

Membrane Filtration. Membrane filtration is a feasible and economic way to fractionate milk components by molecular size in dairy processing, with the first applications of membrane filtration being cheese making and whey processing (Kosikowski, 1974). When applied to fluid milk processing, ultrafiltration (UF) is commonly used to increase or standardize protein concentration while decreasing lactose concentration. There is not much research available regarding the effects of membrane filtration on the sensory properties and consumer acceptance of fluid milk. Trained panel sensory studies suggest, however, that varying the total protein concentration in fluid milk using UF elicits differences in appearance rather than flavor attributes (Quiñones et al., 1997, 1998). However, varying the type of protein (i.e., serum protein and casein) by microfiltration in milk beverages (Cheng et al., 2019a,b) does produce flavor differences; namely, reduced cooked/ sulfur and cardboard/doughy flavor in milk proteinbased beverages containing less milk serum protein as a percentage of the total protein (Cheng et al., 2019b). Serum protein removal can be achieved through microfiltration, and UHT microfiltered milk may have less cooked/sulfur off-flavors than conventional milk. There is a need to determine how much milk serum protein needs to be removed from milk before UHT to eliminate the cooked/sulfur off-flavors. The removal efficiency of serum protein from milk differs among membrane types (i.e., ceramic vs. polymeric), with ceramic microfiltration membranes achieving higher milk serum protein removal from skim milk (Zulewska et al., 2009). It is worth noting that the UF milk brand Fairlife (Fairlife LLC, Chicago, IL), which has 50\% more protein, 30\% more calcium, and 50\% less sugar than regular milk, experienced a $79 \%$ growth in dollar sales in 2016, suggesting high consumer acceptance for UF milk products (Watson, 2017). This observation is also likely due to continually growing consumer interest in added value and functional dairy beverages as well as increased protein (Harwood and Drake, 2018, 2019). More research is necessary to determine consumer acceptance of UF milk products for both adults and children.

\section{Extrinsic Factors}

Social Influence. Social interactions with parents, caregivers, school teachers and staff, and peers can all influence milk consumption and choice in children. The food choices and practices of parents and caregivers can have a powerful influence on the development of eating patterns in children by acting as a provider and model (Savage et al., 2007). Actions of local school boards are affected by voters (parents), and these boards may place additional restrictions on school lunch product offerings (e.g., no high-fructose corn syrup in flavored milks) that make it difficult for milk processors to provide milk that complies with stricter local preferences. As such, education of parents on the health benefits of fluid milk and flavored milk is crucial. For instance, the types and amount of milk consumed by children are highly related to that provided by parents at home (De Pelsmaeker et al., 2013). In one study, students 10 to $16 \mathrm{yr}$ indicated that they believed that their parents would prefer them to drink the same type of milk that they usually consumed at home (Gummeson et al., 1996). Several other studies demonstrated that children demonstrated similar patterns of milk intakes for both amount (Berg et al., 2000; Johnson et al., 2001) and type (Dennison et al., 2001) consumed as their mothers, suggesting that parents serve as models of milk consumption.

In school and childcare settings, peer modeling can also have a large effect on child food and beverage choices. Birch (1980) demonstrated that a child's food choices, preferences, and consumption patterns were greatly influenced by their peers, particularly in young children whose preferences were more malleable. Peer modeling has also been demonstrated with regards to milk consumption in cafeteria settings (Connors et al., 2001; Burgess-Champoux et al., 2016). Encouragement of milk consumption and information regarding milk nutrition by teachers and other school staff has been proposed as a potential social influence for milk consumption (Connors et al., 2001). These studies collectively confirm the findings of McCarthy et al. (2017a) that a unique feature of milk consumption is habit.

Perceived Health Beliefs. Beliefs about health will have an impact on child attitudes toward milk (Berg et al., 2000). Children observe that milk is important for good health, particularly bone and teeth health, but were limited in their ability to explain observations that they made regarding nutrition facts (Connors et al., 2001; Marcinow et al., 2017). In a study with young adults, many were unaware of the health benefits of adequate calcium intake for their age group (Marcinow et al., 2017). Although nutrition is considered by older children, younger children are more likely to focus on 
flavor alone (Gummeson et al., 1996; Connors et al., 2001). Many studies have concluded that although children are knowledgeable about good health and nutrition practices, this may not translate to food choice or dietary behavior (Trexler and Sargent, 1993; Gummeson et al., 1996; Woodward et al., 1996), as food preferences are mainly driven by taste, texture, and appearance (Stevenson et al., 2007; Fitzgerald et al., 2010; Jones et al., 2012). For instance, while children perceive plain milk to be healthier than flavored milk, there is still a clear preference for flavored milk (De Pelsmaeker et al., 2013). One explanation proposed for such observations is that children believe that making food choices based on health is only for adults, whereas children can make food choices based mainly on taste (Chapman and MacLean, 1993; Guidetti et al., 2014).

Children are encouraged to be physically active and many children participate in sports within the school system. Due to milk's carbohydrate, protein, water, and electrolyte content, chocolate milk may aid in recovery from periods of higher physical activity. Several studies with adults have demonstrated enhanced muscle protein synthesis, glycogen restoration, rehydration, reduced muscle soreness, and even enhanced performance (e.g., increased time to exhaustion) when chocolate milk is consumed post-exercise compared with a placebo or other recovery beverages containing carbohydrate, protein, and fat (Pritchett and Pritchett, 2012; Amiri et al., 2019; James et al., 2019; Russo et al., 2019). However, recovery studies are generally done with adolescents and adults, not with younger children. This might be an interesting area where further work is needed. An additional advantage to chocolate milk for exercise recovery is that it is often less costly than other over-the-counter recovery beverages (James et al., 2019). Milk-based beverages and flavored milks can be offered to meet these needs of active students through vending machines in schools.

\section{Packaging Factors}

Graphics and Visual Design Factors. The main purpose of packaging is to contain the product and maintain food safety; however, the package also acts as a marketing vehicle (Harris et al., 2010). Visual appeal of packaging affects consumer acceptance, behavior, and purchase decisions. Many products that are targeted at children use a cartoonish script or crayoned font to identify it as a children's food (Elliott, 2008). Colorful and "fun" packaging is more appealing to children, and in turn increases a child's purchase intention (Pires and Agante, 2011). However, it is important to note that color also creates associations and expectations relating to flavor and sensory properties, particu- larly in milk, where colors are associated with a certain flavor or milkfat content (Connors et al., 2001; Ares and Deliza, 2010). One study found that changing the milk packaging of low-fat plain milk from blue to pink coincided with a gender-specific shift in popularity of that beverage from boys to girls (Wechsler et al., 1998).

A broad range of food and beverage products use promotional characters on packaging, most of which are licensed characters or brand equity characters, but also include celebrities (Hebden et al., 2011). The utilization of licensed media cartoon characters (such as characters from television shows or movies) for food and beverage packaging has been demonstrated to increase the amount of time and number of times a child views a product (McGale et al., 2016; Ogle et al., 2017). Children are more likely to indicate preference for foods when they are associated with characters that they like (Kotler et al., 2012).

Promotional character may increase liking, preference, purchase request, and food choice for multiple kinds of products (Letona et al., 2014; Kraak and Story, 2015). In contrast, the presence of a character has had a counterintuitively negative impact on food choice in some studies (Ogle et al., 2017) and no impact on product preference or choice in others (Neeley and Schumann, 2004). This impact may vary depending on factors such as age, gender, and the specific character used (Ogle et al., 2017). Studies (Letona et al., 2014; Ogle et al., 2017) have reported that younger children (ages 4 to $6 \mathrm{yr}$ ) are more attracted to products with characters than older children (ages 8 to $11 \mathrm{yr}$ ). Similar to age, the Ogle et al. (2017) study found differences in effectiveness of characters depending on the gender toward which they were targeted.

Very little research exists on how visual design factors of packaging affect child acceptance of milk. Valajoozi and Zangi (2016) investigated the impact of packaging attributes on children aged 7 to $14 \mathrm{yr}$ and on their parents in Tehran. They reported that children found the form of the packaging type, color, and illustration to be more important than their parents did, whereas parents found the font style to be more important than children did. In another study, Connors et al. (2001) conducted focus groups with students aged 6 to $11 \mathrm{yr}$ and reported that milk packaging color, graphics, and type influenced student perceptions and experiences with milk. In relation to package type, some students noted that it was difficult to drink out of a gable-top carton without spilling (Connors et al., 2001). A study conducted by the School Nutrition Association and National Dairy Council suggested that children purchased and consumed more milk when it was served in a variety of sizes in resealable plastic bottles (Rafferty et al., 2009). Although the studies discussed provide 
information about which packaging factors are noticed by children, there is a lack of information regarding the relative importance of milk packaging factors for children.

Labeling Factors. Nutrition claims can have a positive impact on child expected liking of a product and health perceptions (Ares et al., 2016). Lima et al. (2019) determined that based solely on packaging information and claims, children from 6 to $12 \mathrm{yr}$ were more likely to select a sugar-reduced product than a full sugar product. However, when the product was tasted, children indicated preference for the full sugar product, even when sugar reduction claims were used on the front of the package. This supports the idea that children's choice for flavored milk is sensory driven rather than health driven. Additionally, children (aged 7 to $12 \mathrm{yr}$ ) were more likely than adolescents (aged 13 to $17 \mathrm{yr}$ ) to describe chocolate-flavored milk with a sugar reduction claim as "good for my health" (Yoo et al., 2017). Frontof-package nutrition labeling tools for children, such as a traffic light or emoticon expressions to convey health messages, have also been found to influence choice and health perceptions. For instance, the use of a red traffic light gives a negative health perception, potentially discouraging the consumption of products higher in sugar (Yoo et al., 2017), whereas a green smiley face emoticon has been shown to increase the purchase of plain fatfree milk without affecting overall milk purchase for children in kindergarten through grade 6 (Siegel et al., 2015).

Branding is an advertising method used to establish recognition and positive associations with a company name or product, with the goal of creating a lifelong customer (Connor, 2006). Brand recognition may be established as early as the age of $2 \mathrm{yr}$ (Valkenburg and Buijzen, 2005). Other studies have found that television advertising of a particular brand influenced young children's food preferences, particularly in children that were overweight (Borzekowski and Robinson, 2001; Halford et al., 2008). The presence of branding alone may be enough to increase the actual intake of a particular food in children who are overweight (Cornwell et al., 2014).

Branding and the use of promotional characters are techniques that are not widely used in the conventional fluid milk category (Smith et al., 2009). In one study with adults in Northern Ireland, consumers viewed milk as a commodity and therefore demonstrated a lack of brand loyalty (Hollywood et al., 2013); however, it is not known whether the same effect would be observed in children. Brand of milk was the least important attribute to consumers for fluid milk overall (McCarthy et al., 2017a; Harwood and Drake, 2018) in US consumers. Similar effects of brand on consumer perceptions have been observed for flavored milk. Kim et al. (2013) reported that brand had no consistent effect on liking of chocolate milk, and brand was less important than labeled milkfat content and sugar content. It should also be noted that there is great public scrutiny regarding the ethics of using brands or promotional characters in advertising food to young children, especially because these tactics are often utilized to promote energy-dense, low-nutrient foods (Elliott, 2008; Harris et al., 2010). However, although research is limited, such techniques could be used to make healthful foods more appealing to children (Cornwell et al., 2014).

Packaging Materials. Packaging material and form has a large effect on the consumer experience as well as the flavor of fluid milk. Milk packaging protects against microbial contamination, light, oxygen, and helps to maintain milk nutritional value during storage (Zygoura et al., 2004). The most common materials used for milk packaging today include high-density polyethylene (HDPE) jugs, polyethylene terephthalate (PET) and polycarbonate bottles, high-impact polystyrene tubs, low-density polyethylene pouches, coated paper containers, and multilayered composite materials (Karaman et al., 2015). Harwood and Drake (2018) reported that packaging type was of low importance to adult consumers; however, the packaging form or shape may create consumer expectations about the product (Ares and Deliza, 2010). For instance, focus groups with consumers in Northern Ireland found that paperboard and nontranslucent containers were less appealing to consumers than packages that allowed them to visually observe and assess the quality of the milk product (Hollywood et al., 2013).

The most popular types of package for fluid milk products are HDPE jugs and bottles (Brody, 2016). They are cost effective, durable, and consumer friendly. Although HDPE provides a good moisture barrier, it is rather ineffective by itself at protecting against oxygen and light. Therefore, milk packaged in HDPE jugs or bottles is susceptible to oxidation of lipids (Cladman et al., 1998) and light oxidation. To combat against light oxidation, multilayer bottles with pigmented with compounds such as titanium dioxide are typically used (Karatapanis et al., 2006). Polyethylene terephthalate packages have the advantage of having mechanical strength while being lightweight, as well as providing a better oxygen barrier than HDPE (Zygoura et al., 2004; Karatapanis et al., 2006). Karatapanis et al. (2006) found that HTST-pasteurized whole milk packaged in both clear and pigmented PET bottles developed plastic and oxidized off-flavors after $5 \mathrm{~d}$ of storage when exposed to fluorescent light, which significantly decreased the flavor quality. Additionally, PET packages did not provide as much light protection as pigmented 
HDPE bottles or paperboard cartons (Karatapanis et al., 2006). A common composite package used for fluid milk packaging in Europe and North America is the tetrahedron, which was developed by Tetra Pak (Pully, Switzerland). It is made from a combination of paperboard, polyethylene coating, and aluminum foil. This form is commonly used for extended shelf-life packaging (Brody, 2016).

Gable-top paperboard cartons are a popular form of packaging for fluid milk in half-gallons or smaller because of their resistance to moisture, cost effectiveness, and ease of graphic application (Brody, 2016). They are produced by extruding a polyethylene layer onto paperboard (Baigrie, 2003). About $93.8 \%$ of the milk sold in the US school lunch program (2017-2018) was in 240$\mathrm{mL}$ paperboard packages, $4.6 \%$ was in plastic bottles, and $1.6 \%$ in pouches (MilkPEP, 2017). A limitation of paperboard cartons is that they are highly susceptible to flavor migration of soluble compounds from the package; namely, from the polyethylene coating to the milk (Leong et al., 1992). Paperboard cartons are also a poor oxygen barrier and they cause stale flavors over storage time (Karatapanis et al., 2006). Gable-top cartons are a concern because, as previously discussed, flavor is the main driver for milk consumption in children. In regard to ease of use, they are more difficult to open than other packaging types and are not reclosable (Brody, 2016).

\section{SUMMARY}

Many factors influence child perceptions of fluid milk, but flavor and habit remain the primary drivers of milk consumption. Forming milk consumption habits during elementary school years is crucial to promote lifelong consumption of milk for improved bone health and well-being. To make milk more appealing to children during these foundational years, consideration must be given to the both the intrinsic and extrinsic properties of fluid milk, as well as the environmental factors under which milk is provided to children in schools. School lunch providers have many specific constraints (total calories, fat as a percent of calories, and sodium level) that they need to satisfy to be eligible for school lunch reimbursement. In addition, they must meet food group criteria for a specific number of servings of fruit, vegetables, and milk per meal. To comply with the limits on total calories per meal and percentage of calories from fat, milk must be restricted to skim or $1 \%$ fat. In addition, school lunch providers need to control the total cost of the lunch per student to function within the budget of the local school district. Even with those constraints, each student is always offered one 240-mL serving of milk per meal in school.
The quality of the skim and $1 \%$ fat milk offered in school meal programs due to low-cost packaging is suboptimal, with sensory properties that students do not like (Sipple, 2019). Deficient on-site handling and storage of milk at the school is often an additional barrier to achieving high satisfaction with milk quality by students. As a result, data on high milk waste show that students take the milk they are offered but only consume part of it. The dairy industry needs to find more cost-effective approaches to provide children with "value-added" milk products, such as products with improved packaging or products reformulated to contain higher protein and calcium, less carbohydrate, hydrolyzed lactose, or natural nonnutritive natural sweeteners with flavors and packaging that students like. There is a need for research to develop milk-based unflavored and flavored beverages with high nutritional quality that children like and prefer over other beverage choices in the cafeteria, food service, and retail marketing of beverage milk to children. A gap in research remains regarding children's preferences for extrinsic properties of fluid milk, especially as it relates to labeling and graphics. Understanding how to create and market milk products that are appealing to children without compromising health outcomes through excessive calorie or fat intake is necessary to increase lifelong milk consumption.

\section{ACKNOWLEDGMENTS}

Funding was provided in part by the National Dairy Council (Rosemont, IL). The authors thank Katie Bambacht, Camellia Patey, and Scott Dissinger from the National Dairy Council for their review and comments that aided in the preparation of the manuscript. Use of names, names of ingredients, and identification of specific models of equipment is for scientific clarity and does not constitute any endorsement of product by authors, North Carolina State University or Cornell University. The authors have not stated any conflicts of interest.

\section{REFERENCES}

Abargouei, A. S., M. Janghorbani, M. Salehi-Marzijarani, and A. Esmaillzadeh. 2012. Effect of dairy consumption on weight and body composition in adults: A systematic review and meta-analysis of randomized controlled clinical trials. Int. J. Obes. (Lond.) 36:1485-1493. https://doi.org/10.1038/ijo.2011.269.

Al-Attabi, Z., B. R. D'Arcy, and H. C. Deeth. 2009. Volatile sulphur compounds in UHT milk. Crit. Rev. Food Sci. Nutr. 49:28-47. https://doi.org/10.1080/10408390701764187.

Al-Attabi, Z., B. R. D'Arcy, and H. C. Deeth. 2014. Volatile sulfur compounds in pasteurised and UHT milk during storage. Dairy Sci. Technol. 94:241-253.

American Dental Association. 2000. Statement on early childhood caries. Accessed Jan. 3, 2020. https://www.ada.org/en/about-the 
-ada/ada-positions-policies-and-statements/statement-on-early -childhood-caries.

Amiri, M., R. Ghiasvand, M. Kaviani, S. C. Forbes, and A. SalehiAbargouei. 2019. Chocolate milk for recovery from exercise: A systematic review and meta-analysis of controlled clinical trials. Eur. J. Clin. Nutr. 73:835-849. https://doi.org/10.1038/s41430 $-018-0187-x$.

Anzman-Frasca, S., J. S. Savage, M. E. Marini, J. O. Fisher, and L. L. Birch. 2012. Repeated exposure and associative conditioning promote preschool children's liking of vegetables. Appetite 58:543553. https://doi.org/10.1016/j.appet.2011.11.012.

Ares, G., A. Arrúa, L. Antúnez, L. Vidal, L. Machín, J. Martínez, M. R. Curutchet, and A. Giménez. 2016. Influence of label design on children's perception of two snack foods: Comparison of rating and choice-based conjoint analysis. Food Qual. Prefer. 53:1-8. https:// doi.org/10.1016/j.foodqual.2016.05.006.

Ares, G., and R. Deliza. 2010. Studying the influence of package shape and colour on consumer expectations of milk desserts using word association and conjoint analysis. Food Qual. Prefer. 21:930-937. https://doi.org/10.1016/j.foodqual.2010.03.006

Baigrie, B. 2003. Packaging materials as a source of taints. Pages 64111 in Taints and Off-Flavours in Food. CRC Press, Boca Raton, FL

Bakke, A. J., C. V. Shehan, and J. E. Hayes. 2016. Type of milk typically consumed, and stated preference, but not health consciousness affect revealed preferences for fat in milk. Food Qual. Prefer. 49:92-99. https://doi.org/10.1016/j.foodqual.2015.12.001.

Beckerman, J. P., S. A. Blondin, S. A. Richardson, and E. B. Rimm. 2019. Environmental and economic effects of changing to shelf-stable dairy or soy milk for the breakfast in the classroom program. Am. J. Public Health 109:736-738. https://doi.org/10.2105/AJPH .2019.304956.

Berg, C., I. Jonsson, and M. Conner. 2000. Understanding choice of milk and bread for breakfast among Swedish children aged 11-15 years: An application of the Theory of Planned Behaviour. Appetite 34:5-19. https://doi.org/10.1006/appe.1999.0269.

Birch, L. L. 1980. Effects of peer models' food choices and eating behaviors on preschoolers' food preferences. Child Dev. 51:489-496. https://doi.org/10.2307/1129283.

Black, R. E., S. M. Williams, I. E. Jones, and A. Goulding. 2002. Children who avoid drinking cow milk have low dietary calcium intakes and poor bone health. Am. J. Clin. Nutr. 76:675-680. https://doi .org/10.1093/ajen/76.3.675.

Blondin, S. A., S. B. Cash, J. P. Goldberg, T. S. Griffin, and C. D. Economos. 2017. Nutritional, economic, and environmental costs of milk waste in a classroom school breakfast program. Am. J. Public Health 107:590-592. https://doi.org/10.2105/AJPH.2016 .303647.

Borzekowski, D. L., and T. N. Robinson. 2001. The 30-second effect: An experiment revealing the impact of television commercials on food preferences of pre-schoolers. J. Am. Diet. Assoc. 101:42-46. https://doi.org/10.1016/S0002-8223(01)00012-8.

Brody, A. L. 2016. Packaging milk and milk products. Pages 506-527 in Dairy Processing and Quality Assurance. 2nd ed. John Wiley and Sons, Hoboken, NJ.

Buczkowski, B., E. Smith, and A. Turner. 2018. Acceptability of chocolate-flavored milk with reduced sucrose content in schoolchildren. Proc. Nutr. Soc. 77(OCE4):E228.

Burgess-Champoux, T. L., R. Rosen, W. Linsenmeyer, H. Faivre, C. Longley, S. English, B. W. Rice, E. L. Shanley, R. Cosby, C. Strohbehn, and S. Arendt. 2016. Got milk! Exploring how student perceptions and behaviors impact their milk selection in schools. Institute of Child Nutrition. Applied Research Division, Hattiesburg, MS. Accessed Jan. 1, 2020. https://theicn.org/resources/ 347/technical-reports/106623/Got-Milk-Exploring-How-Student -Perceptions-Impact-Their-Milk-Selection-in-Schools.pdf.

Castillo, J. L., P. Milgrom, S. E. Coldwell, R. Castillo, and R. Lazo. 2005. Children's acceptance of milk with xylitol or sorbitol for dental caries prevention. BMC Oral Health 5:6. https://doi.org/10 $.1186 / 1472-6831-5-6$.
Chapman, G., and H. MacLean. 1993. "Junk food" and "healthy food": Meanings of food in adolescent women's culture. J. Nutr. Educ. 25:108-113. https://doi.org/10.1016/S0022-3182(12)80566-8.

Chapman, K. W., and K. Boor. 2001. Acceptance of $2 \%$ ultra-pasteurized milk by consumers, 6 to 11 years old. J. Dairy Sci. 84:951-954. https://doi.org/10.3168/jds.S0022-0302(01)74553-5.

Chen, A. W., A. V. A. Resurreccion, and L. P. Paguio. 1996. Age appropriate hedonic scales to measure food preferences of young children. J. Sens. Stud. 11:141-163. https://doi.org/10.1111/j.1745 -459X.1996.tb00038.x.

Cheng, N., D. M. Barbano, and M. A. Drake. 2019a. Effect of pasteurization and fat, protein, casein to serum protein ratio, and milk temperature on milk beverage color and viscosity. J. Dairy Sci. 102:2022-2043. https://doi.org/10.3168/jds.2018-15739.

Cheng, N., D. M. Barbano, and M. A. Drake. 2019b. Effects of milk fat, casein, and serum protein concentrations on sensory properties of milk-based beverages. J. Dairy Sci. 102:8670-8690. https://doi .org/10.3168/jds.2018-16179.

Chojnicka-Paszun, A., H. De Jongh, and C. De Kruif. 2012. Sensory perception and lubrication properties of milk: Influence of fat content. Int. Dairy J. 26:15-22. https://doi.org/10.1016/j.idairyj.2012 .04 .003 .

Cladman, W., S. Scheffer, N. Goodrich, and M. W. Griffiths. 1998 Shelf-life of milk packaged in plastic containers with and without treatment to reduce light transmission. Int. Dairy J. 8:629-636. https://doi.org/10.1016/S0958-6946(98)00094-6.

Code of Federal Regulations. 2019a. Title 7. Agriculture Subtitle B Regulations of the Department of Agriculture. Chapter II. Food and Nutrition service, Department of Agriculture. Subchapter A. Child Nutrition Programs. Part 210. National School Lunch Program. Sub part C. Requirements of School Food Authority Participation. Section 210.10. Meal requirement for lunches and requirements for afterschool snacks. Accessed Jan. 1, 2020. https://www.ecfr.gov/ cgi-bin/text-idx?SID =4c211a738d6109939c6054a6286ac109\&mc= true\&node=pt7.4.210\&rgn=div5\#se7.4.210_110.

Code of Federal Regulations. 2019b. Title 21-Food and Drugs. Chapter I-Food and Drug Administration. Department of Health and Human Services. Subchapter B-Food for Human Consumption PART 131 - Milk and Cream. Subpart A-General Provisions Sec. 131.3 Definitions. Accessed Jan. 1, 2020. https://www.accessdata .fda.gov/scripts/cdrh/cfdocs/cfcfr/CFRSearch.cfm?fr=131.3.

Condon, E. M., E. K. Crepinsek, and M. K. Fox. 2009. School meals: Types of foods offered to and consumed by children at lunch and breakfast. J. Am. Diet. Assoc. 109:S67-S78. https://doi.org/10 1016/j.jada.2008.10.062

Connor, S. M. 2006. Food-related advertising on preschool television: Building brand recognition in young viewers. Pediatrics 118:14781485. https://doi.org/10.1542/peds.2005-2837.

Connors, P., C. Bednar, and S. Klammer. 2001. Cafeteria factors that influence milk-drinking behaviors of elementary school children: Grounded theory approach. J. Nutr. Educ. 33:31-36. https://doi .org/10.1016/s1499-4046(06)60007-9

Cornwell, T. B., A. R. McAlister, and N. Polmear-Swendris. 2014 Children's knowledge of packaged and fast food brands and their BMI. Why the relationship matters for policy makers. Appetite 81:277-283. https://doi.org/10.1016/j.appet.2014.06.017.

Davis, M. M., M. Spurlock, K. Ramsey, J. Smith, B. A. Beamer, S. Aromaa, and P. B. McGinnis. 2017. Milk options observation (MOO): A mixed-methods study of chocolate milk removal on beverage consumption and student/staff behaviors in a rural elementary school. J. Sch. Nurs. 33:285-298. https://doi.org/10 $.1177 / 1059840517703744$.

De Pelsmaeker, S., J. Schouteten, and X. Gellynck. 2013. The consumption of flavored milk among a children population. The influence of beliefs and the association of brands with emotions. Appetite 71:279-286. https://doi.org/10.1016/j.appet.2013.08.016.

Dennison, B. A., T. A. Erb, and P. L. Jenkins. 2001. Predictors of dietary milk fat intake by preschool children. Prev. Med. 33:536-542. https://doi.org/10.1006/pmed.2001.0939.

Dougkas, A., S. Barr, S. Reddy, and C. D. Summerbell. 2019. A critical review of the role of milk and other dairy products in the de- 
velopment of obesity in children and adolescents. Nutr. Res. Rev. 32:106-127. https://doi.org/10.1017/S0954422418000227.

Dror, D. K., and L. H. Allen. 2014. Dairy product intake in children and adolescents in developed countries: Trends, nutritional contribution, and a review of association with health outcomes. Nutr. Rev. 72:68-81. https://doi.org/10.1111/nure.12078.

Dunning, J. M., and A. T. Hodge. 1971. Influence of cocoa and sugar in milk on dental caries incidence. J. Dent. Res. 50:854-859. https: //doi.org/10.1177/00220345710500041101.

Elliott, C. 2008. Assessing 'fun foods': Nutritional content and analysis of supermarket foods targeted at children. Obes. Rev. 9:368-377. https://doi.org/10.1111/j.1467-789X.2007.00418.x.

Eysteinsdottir, T., T. I. Halldorsson, I. Thorsdottir, G. Sigurdsson, S. Sigurð̋sson, T. Harris, L. J. Launer, V. Gudnason, L. Gunnarsdottir, and L. Steingrimsdottir. 2014. Milk consumption throughout life and bone mineral content and density in elderly men and women. Osteoporos. Int. 25:663-672. https://doi.org/10.1007/s00198 $-013-2476-5$.

Fayet-Moore, F. 2016. Effect of flavored milk vs plain milk on total milk intake and nutrient provision in children. Nutr. Rev. 74:1-17. https://doi.org/10.1093/nutrit/nuv031.

Federal Register. 2008. 7CFR 210 and 220 [FNS-2007-0032] RIN 0584AD58. Fluid Milk Substitutions in the School Nutrition Programs. USDA Food and Nutrition Service. Accessed Jan. 1, 2020. https:/ /www.federalregister.gov/documents/2008/09/12/E8-21293/fluid -milk-substitutions-in-the-school-nutrition-programs.

Federal Register. 2017. Child Nutrition Programs: Flexibilities for Milk, Whole Grains, and Sodium Requirements. USDA Food and Nutrition Service. Accessed Jan. 1, 2020. https://www.govinfo .gov/content/pkg/FR-2017-11-30/pdf/2017-25799.pdf.

Federal Register. 2018. 7CFR Parts 210, 215, 220, and 226 [FNS2017-0021] RIN 0584-AE53. Final Rule: Child Nutrition Programs: Flexibilities for Milk, Whole Grains, and Sodium Requirements. USDA Food and Nutrition Service. Accessed Jan. 1, 2020. https: //www.federalregister.gov/documents/2017/11/30/2017-25799/ child-nutrition-programs-flexibilities-for-milk-whole-grains-and -sodium-requirements.

Federal Register. 2019. National School Lunch, Special Milk, and School Breakfast Programs: National Average Payments/Maximum Reimbursement Rates. USDA Food and Nutrition Service. Accessed Jan. 1, 2020. https://www.federalregister.gov/documents/2019/ 08/07/2019-16903/national-school-lunch-special-milk-and-school -breakfast-programs-national-average-paymentsmaximum.

Fitzgerald, A., C. Heary, E. Nixon, and C. Kelly. 2010. Factors influencing the food choices of Irish children and adolescents: A qualitative investigation. Health Promot. Int. 25:289-298. https://doi .org/10.1093/heapro/daq021.

Forrestal, S., C. Cabili, C. Logan, P. Connor, M. Boyle, and A. Enver. 2019. School Nutrition and Meal Cost Study. Final Report Volume 1: School Meal Program Operations and School Nutrition Environments. USDA Food and Nutrition Service, Office of Policy Support. Accessed Dec. 31, 2019. https://fns-prod.azureedge.net/ sites/default/files/resource-files/SNMCS-Volume1.pdf.

Fox, M. K., E. Gearan, C. Cabili, D. Dotter, K. Niland, L. Washburn, and E. N. Paxton. 2019. School Nutrition and Meal Cost Study. Final Report Volume 4: Student Participation, Satisfaction, Plate Waste, and Dietary Intakes. USDA Food and Nutrition Service, Office of Policy Support. Accessed Dec. 31, 2019. https://fns-prod .azureedge.net/sites/default/files/resource-files/SNMCS-Volume4 .pdf.

Frøst, M. B., G. Dijksterhuis, and M. Martens. 2001. Sensory perception of fat in milk. Food Qual. Prefer. 12:327-336. https://doi.org/ 10.1016/S0950-3293(01)00018-0.

Gearan, E., M. K. Fox, K. Niland, D. Dotter, and L. Washburn. 2019. School Nutrition and Meal Cost Study Final Report Volume 2: Nutritional Characteristics of School Meals. USDA Food and Nutrition Service, Office of Policy and Support. Accessed Jun. 3, 2020. https://fnsprod.azureedge.net/sites/default/files/resource -files/SNMCS-Volume2.pdf.

Green, B. P., L. Turner, E. Stevenson, and P. L. S. Rumbold. 2015. Patterns of dairy consumption in free-living children and ado- lescents. J. Dairy Sci. 98:3701-3705. https://doi.org/10.3168/jds .2014-9161.

Guéguen, L., and A. Pointillart. 2000. The bioavailability of dietary calcium. J. Am. Coll. Nutr. 19(Suppl. 2):119S-136S.

Guidetti, M., N. Cavazza, and A. R. Graziani. 2014. Healthy at home, unhealthy outside: Food groups associated with family and friends and the potential impact on attitude and consumption. J. Soc. Clin. Psychol. 33:343-364. https://doi.org/10.1521/jscp.2014.33.4 .343 .

Guinard, J.-X. 2000. Sensory and consumer testing with children. Trends Food Sci. Technol. 11:273-283. https://doi.org/10.1016/ S0924-2244(01)00015-2.

Gummeson, L., I. Jonsson, M. Conner, and E. Svensson. 1996. Assessing factors influencing food choice among 10-16-year-old schoolboys. A pilot study with a stacking box method. J. Hum. Nutr. Diet. 9:219-229. https://doi.org/10.1046/j.1365-277X.1996.00451 .x.

Gunderson, G. 2017. National School Lunch Program (NSLP): School milk programs. Accessed Jan. 1, 2020. Accessed Jun. 3, 2020. https://fns-prod.azureedge.net/sites/default/files/resource-files/ NSLP-Program $\% 20$ History.pdf.

Gupta, P., N. Gupta, A. P. Pawar, S. S. Birajdar, A. S. Natt, and H. P. Singh. 2013. Role of sugar and sugars substitutes in dental caries: A review. ISRN Dent. 2013:519421. https://doi.org/10.1155/ $2013 / 519421$.

Halford, J. C., E. J. Boyland, G. D. Cooper, T. M. Dovey, C. J. Smith, N. Williams, C. L. Lawton, and J. E. Blundell. 2008. Children's food preferences: Effects of weight status, food type, branding and television food advertisements (commercials). Int. J. Pediatr. Obes. 3:31-38. https://doi.org/10.1080/17477160701645152.

Harris, J. L., M. B. Schwartz, and K. D. Brownell. 2010. Marketing foods to children and adolescents: Licensed characters and other promotions on packaged foods in the supermarket. Public Health Nutr. 13:409-417. https://doi.org/10.1017/S1368980009991339.

Harwood, W. S., and M. A. Drake. 2018. Identification and characterization of fluid milk consumer groups. J. Dairy Sci. 101:8860-8874. https://doi.org/10.3168/jds.2018-14855.

Harwood, W. S., and M. A. Drake. 2019. Understanding implicit and explicit consumer desires for protein bars, powders, and beverages. J. Sens. Stud. 34:e12493. https://doi.org/10.1111/joss.12493.

Hebden, L., L. King, B. Kelly, K. Chapman, and C. Innes-Hughes. 2011. A menagerie of promotional characters: Promoting food to children through food packaging. J. Nutr. Educ. Behav. 43:349355. https://doi.org/10.1016/j.jneb.2010.11.006.

Henry, C., S. J. Whiting, T. Phillips, S. L. Finch, G. A. Zello, and H. Vatanparast. 2015. Impact of the removal of chocolate milk from school milk programs for children in Saskatoon, Canada. Appl. Physiol. Nutr. Metab. 40:245-250. https://doi.org/10.1139/apnm $-2014-0242$.

Henry, C., S. J. Whiting, S. L. Finch, G. A. Zello, and H. Vatanparast. 2016. Impact of replacing regular chocolate milk with the reducedsugar option on milk consumption in elementary schools in Saskatoon, Canada. Appl. Physiol. Nutr. Metab. 41:511-515. https:// doi.org/10.1139/apnm-2015-0501.

Hollywood, L., L. Wells, G. Armstrong, and H. Farley. 2013. Thinking outside the carton: Attitudes towards milk packaging. Br. Food J. 115:899-912. https://doi.org/10.1108/BFJ-Jul-2010-0127.

Horwath, C. C., C. H. Govan, A. J. Campbell, W. Busby, and V. Scott. 1995. Factors influencing milk and milk product consumption in young and elderly women with low calcium intakes. Nutr. Res. 15:1735-1745. https://doi.org/10.1016/0271-5317(95)02043-8.

Huth, P. J., D. DiRienzo, and G. Miller. 2006. Major scientific advances with dairy foods in nutrition and health. J. Dairy Sci. 89:12071221. https://doi.org/10.3168/jds.S0022-0302(06)72190-7.

Institute of Medicine. 2010. Dietary Reference Intakes for Calcium and Vitamin D. Institute of Medicine of the National Academies, Washington, DC. Accessed Jan. 1, 2020. https://www.ncbi.nlm .nih.gov/books/NBK56070/.

James, L. J., E. J. Stevenson, P. L. Rumbold, and C. J. Hulston. 2019. Cow's milk as a post-exercise recovery drink: Implications for per- 
formance and health. Eur. J. Sport Sci. 19:40-48. https://doi.org/ 10.1080/17461391.2018.1534989.

Jo, Y., B. Carter, D. M. Barbano, and M. A. Drake. 2019. Identification of the source of volatile sulfur compounds produced in milk during thermal processing. J. Dairy Sci. 102:8658-8669. https:// doi.org/10.3168/jds.2019-16607.

Johnson, R. K., C. Frary, and M. Q. Wang. 2002. The nutritional consequences of flavored-milk consumption by school-aged children and adolescents in the United States. J. Am. Diet. Assoc. 102:853-856. https://doi.org/10.1016/S0002-8223(02)90192-6.

Johnson, R. K., C. V. Panely, and M. Q. Wang. 2001. Associations between the milk mothers drink and the milk consumed by their school-aged children. Fam. Econ. Nutr. Rev. 13:27-36.

Johnson, S. L., L. McPhee, and L. Birch. 1991. Conditioned preferences: Young children prefer flavors associated with high dietary fat. Physiol. Behav. 50:1245-1251. https://doi.org/10.1016/0031 -9384(91)90590-K.

Jones, S., S. Reis, and P. Gregory. 2012. What I say isn't always what I do: Investigating differences in children's reported and actual snack food preferences. Int. J. Child Health Nutr. 1:28-38. https:/ /doi.org/10.6000/1929-4247.2012.01.01.04.

Kalkwarf, H. J., J. C. Khoury, and B. P. Lanphear. 2003. Milk intake during childhood and adolescence, adult bone density, and osteoporotic fractures in US women. Am. J. Clin. Nutr. 77:257-265. https://doi.org/10.1093/ajen/77.1.257.

Karaman, A. D., B. Özer, M. A. Pascall, and V. Alvarez. 2015. Recent advances in dairy packaging. Food Rev. Int. 31:295-318. https:// doi.org/10.1080/87559129.2015.1015138.

Karatapanis, A. E., A. V. Badeka, K. A. Riganakos, I. N. Savvaidis, and M. G. Kontominas. 2006. Changes in flavour volatiles of whole pasteurized milk as affected by packaging material and storage time. Int. Dairy J. 16:750-761. https://doi.org/10.1016/j.idairyj 2005.06.008

Kelder, S. H., C. L. Perry, K. I. Klepp, and L. L. Lytle. 1994. Longitudinal tracking of adolescent smoking, physical activity, and food choice behaviors. Am. J. Public Health 84:1121-1126. https://doi .org/10.2105/AJPH.84.7.1121.

Kern, D. L., L. McPhee, J. Fisher, S. Johnson, and L. L. Birch. 1993. The postingestive consequences of fat condition preferences for flavors associated with high dietary fat. Physiol. Behav. 54:71-76. https://doi.org/10.1016/0031-9384(93)90045-H.

Kildegaard, H., M. Lokke, and A. Thybo. 2011. Effect of increased fruit and fat content in an acidified milk product on preference, liking and wanting in children. J. Sens. Stud. 26:226-236. https:// doi.org/10.1111/j.1745-459X.2011.00338.x.

Kim, M. K., K. Lopetcharat, and M. Drake. 2013. Influence of packaging information on consumer liking of chocolate milk. J. Dairy Sci. 96:4843-4856. https://doi.org/10.3168/jds.2012-6399.

Kit, B. K., M. D. Carroll, and C. L. Ogden. 2011. Low-fat milk consumption among children and adolescents in the United State, 2007-2008. NCHS Data Brief 75. National Center for Health Statistics, Hyattsville, MD. Accessed Dec. 31, 2019. https://www.cdc .gov/nchs/data/databriefs/db75.pdf.

Kling, S. M., L. S. Roe, C. E. Sanchez, and B. J. Rolls. 2016. Does milk matter: Is children's intake affected by the type or amount of milk served at a meal? Appetite 105:509-518. https://doi.org/10 .1016/j.appet.2016.06.022.

Kosikowski, F. V. 1974. Cheesemaking by ultrafiltration. J. Dairy Sci. 57:488-491. https://doi.org/10.3168/jds.S0022-0302(74)84920-9.

Kotler, J. A., J. M. Schiffman, and K. G. Hanson. 2012. The influence of media characters on children's food choices. J. Health Commun. 17:886-898. https://doi.org/10.1080/10810730.2011.650822.

Kraak, V. I., and M. Story. 2015. Influence of food companies' brand mascots and entertainment companies' cartoon media characters on children's diet and health: A systematic review and research needs. Obes. Rev. 16:107-126. https://doi.org/10.1111/obr.12237.

Lee, A. P., D. M. Barbano, and M. A. Drake. 2017. The influence of ultra-pasteurization by indirect heating versus direct steam injection on skim and $2 \%$ fat milks. J. Dairy Sci. 100:1688-1701. https: //doi.org/10.3168/jds.2016-11899.
Leong, C., B. Harte, J. Partridge, D. Ott, and T. Downes. 1992. Offflavor development in milk packaged in polyethylene-coated paperboard cartons. J. Dairy Sci. 75:2105-2111. https://doi.org/10 .3168/jds.S0022-0302(92)77969-7.

Letona, P., V. Chacon, C. Roberto, and J. Barnoya. 2014. Effects of licensed characters on children's taste and snack preferences in Guatemala, a low/middle income country. Int. J. Obes. (Lond.) 38:1466-1469. https://doi.org/10.1038/ijo.2014.38.

Li, X. E., K. Lopetcharat, and M. A. Drake. 2014. Extrinsic attributes that influence parents' purchase of chocolate milk for their children. J. Food Sci. 79:S1407-S1415. https://doi.org/10.1111/1750 $-3841.12515$.

Li, X. E., K. Lopetcharat, and M. A. Drake. 2015b. Parents' and children's acceptance of skim chocolate milks sweetened by monk fruit and stevia leaf extracts. J. Food Sci. 80:S1083-S1092. https://doi .org/10.1111/1750-3841.12835.

Li, X. E., K. Lopetcharat, Y. Qiu, and M. A. Drake. 2015a. Sugar reduction of skim chocolate milk and viability of alternative sweetening through lactose hydrolysis. J. Dairy Sci. 98:1455-1466. https:/ /doi.org/10.3168/jds.2014-8490.

Liem, D. G., D. Bolhuis, X. Hu, and R. Keast. 2016. Influence of labeling on Australian and Chinese consumers' liking of milk with short (pasteurized) and long (UHT) shelf life. J. Dairy Sci. 99:17471754. https://doi.org/10.3168/jds.2015-10516.

Lima, M., M. de Alcantara, G. Ares, and R. Deliza. 2019. It is not all about information! Sensory experience overrides the impact of nutrition information on consumers' choice of sugar-reduced drinks. Food Qual. Prefer. 74:1-9. https://doi.org/10.1016/j.foodqual .2018.12.013.

Logan, C. W., V. Tran, M. Boyle, A. Envers, M. Zeidenburg, and M. Mendelson. 2019. School Nutrition and Meal Cost Study, Final Report Volume 3: School Meal Costs and Revenues. USDA Food and Nutrition Service, Office of Policy Support. Accessed Jan. 1, 2020. https://www.mathematica.org/our-publications-and -findings/publications/school-nutrition-and-meal-cost-study-final -report-volume-3-school-meal-costs-and-revenues.

Marcinow, M. L., J. A. Randall Simpson, S. J. Whiting, M. E. Jung, and A. C. Buchholz. 2017. Young adults' perceptions of calcium intake and health: A qualitative study. Health Educ. Behav. 44:898906. https://doi.org/10.1177/1090198116688439.

McCain, H. R., S. Kaliappan, and M. A. Drake. 2018. Sugar reduction in dairy products. J. Dairy Sci. 101:8619-8640. https://doi.org/10 .3168/jds.2017-14347.

McCarthy, K. S., K. Lopetcharat, and M. A. Drake. 2017b. Milk fat threshold determination and the effect of milk fat content on consumer preference for fluid milk. J. Dairy Sci. 100:1702-1711. https: //doi.org/10.3168/jds.2016-11417.

McCarthy, K. S., M. Parker, A. Ameerally, S. L. Drake, and M. A. Drake. 2017a. Drivers of choice for fluid milk versus plant-based alternatives: What are consumer perceptions of fluid milk? J. Dairy Sci. 100:6125-6138. https://doi.org/10.3168/jds.2016-12519.

McGale, L. S., J. C. G. Halford, J. A. Harrold, and E. J. Boyland. 2016. The influence of brand equity characters on children's food preferences and choices. J. Pediatr. 177:33-38. https://doi.org/10 .1016/j.jpeds.2016.06.025.

MilkPEP. 2017. 2017 MilkPEP All Channel Tracking conducted by Prime Consulting. MilkPEP, Washington, DC.

Moore, L. L., M. L. Bradlee, D. Gao, and M. R. Singer. 2008. Effects of average childhood dairy intake on adolescent bone health. J. Pediatr. 153:667-673. https://doi.org/10.1016/j.jpeds.2008.05.016.

Murphy, M. M., J. S. Douglass, R. K. Johnson, and L. A. Spence. 2008. Drinking flavored or plain milk is positively associated with nutrient intake and is not associated with adverse effects on weight status in US children and adolescents. J. Am. Diet. Assoc. 108:631-639. https://doi.org/10.1016/j.jada.2008.01.004.

Neeley, S. M., and D. W. Schumann. 2004. Using animated spokescharacters in advertising to young children: Does increasing attention to advertising necessarily lead to product preference? J. Advert. 33:7-23. https://doi.org/10.1080/00913367.2004.10639166. 
Nicklas, T. A., C. E. O'Neil, and V. L. Fulgoni III.. 2013. The nutritional role of flavored and white milk in the diets of children. J. Sch. Health 83:728-733. https://doi.org/10.1111/josh.12087.

Nicklas, T. A., C. O'Neil, and V. Fulgoni III.. 2017. Flavored milk consumers drank more milk and had a higher prevalence of meeting calcium recommendation than nonconsumers. J. Sch. Health 87:650-657. https://doi.org/10.1111/josh.12537.

Nicklaus, S., V. Boggio, C. Chabanet, and S. Issanchou. 2004. A prospective study of food preferences in childhood. Food Qual. Prefer. 15:805-818. https://doi.org/10.1016/j.foodqual.2004.02.010.

Noel, S. E., A. R. Ness, K. Northstone, P. Emmett, and P. K. Newby. 2013. Associations between flavored milk consumption and changes in weight and body composition over time: Differences among normal and overweight children. Eur. J. Clin. Nutr. 67:295-300. https://doi.org/10.1038/ejcn.2012.123.

Nu, C. T., P. MacLeod, and J. Barthelemy. 1996. Effects of age and gender on adolescents' food habits and preferences. Food Qual. Prefer. 7:251-262. https://doi.org/10.1016/S0950-3293(96)00023 -7 .

Ogle, A. D., D. J. Graham, R. G. Lucas-Thompson, and C. A. Roberto. 2017. Influence of cartoon media characters on children's attention to and preference for food and beverage products. J. Acad. Nutr. Diet. 117:265-270.e2. https://doi.org/10.1016/j.jand 2016.08.012.

Oliveira, D., F. Reis, R. Deliza, A. Rosenthal, A. Giménez, and G. Ares. 2016. Difference thresholds for added sugar in chocolateflavoured milk: Recommendations for gradual sugar reduction. Food Res. Int. 89:448-453. https://doi.org/10.1016/j.foodres.2016 .08 .019 .

Parker, M. N., K. Lopetcharat, and M. A. Drake. 2018. Consumer acceptance of natural sweeteners in protein beverages. J. Dairy Sci. 101:8875-8889. https://doi.org/10.3168/jds.2018-14707.

Patel, A. I., S. D. Moghadam, M. Freedman, A. Hazari, M. Fang, and I. E. Allen. 2018. The association of flavored milk consumption with milk and energy intake, and obesity: A systematic review. Prev. Med. 111:151-162. https://doi.org/10.1016/j.ypmed.2018.02 .031 .

Patterson, J., and M. Saidel. 2009. The removal of flavored milk in schools results in a reduction in total milk purchases in all grades, K-12. J. Am. Diet. Assoc. 109(Suppl.):A97. https://doi.org/10 .1016/j.jada.2009.06.330.

Phillips, L. G., and D. M. Barbano. 1997. The influence of fat substitutes based on protein and titanium dioxide on the sensory properties of low-fat milks. J. Dairy Sci. 80:2726-2731. https://doi.org/ 10.3168/jds.S0022-0302(97)76234-9.

Phillips, L. G., M. L. McGiff, D. M. Barbano, and H. T. Lawless. 1995. The influence of fat on the sensory properties, viscosity, and color of low-fat milk. J. Dairy Sci. 78:1258-1266. https://doi.org/ 10.3168/jds.S0022-0302(95)76746-7.

Pires, C., and L. Agante. 2011. Encouraging children to eat more healthily: The influence of packaging. J. Consum. Behav. 10:161168. https://doi.org/10.1002/cb.362.

Porubcan, A. R., and Z. M. Vickers. 2005. Characterizing milk aftertaste: The effects of salivation rate, PROP taster status, or small changes in acidity, fat, or sucrose on acceptability of milk to milk dislikers. Food Qual. Prefer. 16:608-620. https://doi.org/10.1016/ j.foodqual.2005.01.007.

Pritchett, K., and R. Pritchett. 2012. Chocolate milk: A post-exercise recovery beverage for endurance sports. Med. Sport Sci. 59:127134. https://doi.org/10.1159/000341954.

Quann, E. E., and D. Adams. 2013. Impact on milk consumption and nutrient intakes from eliminating flavored milk in elementary schools. Nutr. Today 48:127-134. https://doi.org/10.1097/NT $.0 \mathrm{~b} 013 \mathrm{e} 3182941 \mathrm{~d} 6 \mathrm{a}$.

Quiñones, H. J., D. M. Barbano, and L. G. Philips. 1998. Influence of protein standardization by ultrafiltration on the viscosity, color, and sensory properties of 2 and 3.3\% milks. J. Dairy Sci. 81:884894. https://doi.org/10.3168/jds.S0022-0302(98)75647-4.

Quiñones, H. J., D. M. Barbano, and L. G. Phillips. 1997. Influence of protein standardization by ultrafiltration on the viscosity, color, and sensory properties of skim and 1\% milk. J. Dairy Sci. 80:31423151. https://doi.org/10.3168/jds.S0022-0302(97)76285-4.

Rafferty, K., and R. P. Heaney. 2008. Nutrient effects on the calcium economy: Emphasizing the potassium controversy. J. Nutr. 138:166S-171S. https://doi.org/10.1093/jn/138.1.166S.

Rafferty, K., D. Zipay, C. Patey, and J. Meyer. 2009. Milk enhancements improve milk consumption and increase meal participation in the NSLP: The school milk pilot test. J. Child Nutr. Manag. 33:431-445.

Rautiainen, S., L. Wang, I. Lee, J. E. Manson, J. E. Buring, and H. D. Sesso. 2016. Dairy consumption in association with weight change and risk of becoming overweight or obese in middle-aged and older women: A prospective cohort study. Am. J. Clin. Nutr. 103:979-988. https://doi.org/10.3945/ajcn.115.118406.

Richard B. Russell National School Lunch Act. 2019. Accessed Dec. 31, 2020. https://www.fns.usda.gov/richard-b-russell-national -school-lunch-act.

Robb, C. A., L. M. Reynolds, and M. Abdel-Ghany. 2007. Consumer preference among fluid milks: Low-fat vs. high-fat milk consumption in the United States. Int. J. Consum. Stud. 31:90-94. https:/ /doi.org/10.1111/j.1470-6431.2006.00492.x.

Ross, A. C., C. L. Taylor, A. L. Yaktine, and H. B. Del Vale, ed. 2011. 2, Overview of calcium. Dietary Reference Intakes for Calcium and Vitamin D. Institute of Medicine (US) Committee to Review Dietary Reference Intakes for Vitamin D and Calcium; National Academies Press, Washington, DC. Accessed Jan. 2, 2020. https:/ /www.ncbi.nlm.nih.gov/books/NBK56070/.

Russo, I., V. Comões-Costa, S. K. Gaskell, J. Porter, L. M. Burke, and R. J. S. Costa. 2019. The effect of dairy milk on markers of recovery optimisation in response to endurance exercise. Int. J. Sports Sci. 9:69-85. https://doi.org/10.5923/j.sports.20190904.01.

Sandler, R. B., C. W. Slemenda, R. E. LaPorte, J. A. Cauley, M. M. Schramm, M. L. Barresi, and A. M. Kriska. 1985. Postmenopausal bone density and milk consumption in childhood and adolescence. Am. J. Clin. Nutr. 42:270-274. https://doi.org/10.1093/ajcn/42 .2 .270 .

Savage, J. S., J. O. Fisher, and L. L. Birch. 2007. Parental influence on eating behavior: Conception to adolescence. J. Law Med. Ethics 35:22-34. https://doi.org/10.1111/j.1748-720X.2007.00111.x.

Sebastian, R. S., J. D. Goldman, C. W. Enns, and R. P. LaComb. 2010. Fluid milk consumption in the United States. Accessed Dec. 31, 2019. www.ars.usda.gov/ARSUserFiles/80400530/pdf/DBrief/ 3_milk_consumption_0506.pdf.

Siegel, R. M., A. Anneken, C. Duffy, K. Simmons, M. Hudgens, M. Kate Lockhart, and J. Shelly. 2015. Emoticon use increases plain milk and vegetable purchase in a school cafeteria without adversely affecting total milk purchase. Clin. Ther. 37:1938-1943. https:/ /doi.org/10.1016/j.clinthera.2015.07.016.

Sipple, L. R. 2019. Evaluation of children's perceptions of fluid milk properties for school meal programs. MS thesis, Department of Food, Bioprocessing and Nutrition Sciences, North Carolina State University, Raleigh.

Skinner, J. D., B. R. Carruth, W. Bounds, and P. J. Ziegler. 2002. Children's food preferences: A longitudinal analysis. J. Am. Diet. Assoc. 102:1638-1647. https://doi.org/10.1016/S0002-8223(02)90349 -4 .

Smith, M. A., M. H. Wells, M. Scarbecz, C. V. Vinall, and M. A. Woods. 2019. Parents' preferences and perceptions of their children's consumption of sugar and non-nutritive sugar substitutes. Pediatr. Dent. 41:119-128.

Smith, T., C. Huang, and B. Lin. 2009. Estimating organic premiums in the US fluid milk market. Renew. Agric. Food Syst. 24:197-204. https://doi.org/10.1017/S1742170509002579.

Stallings, V. A., C. W. Suitor, and C. L. Taylor. 2010. School meals: Building blocks for healthy children. Institute of Medicine (US) Committee on Nutrition Standards for National School Lunch and Breakfast Programs. Natl. Acad. Press, Washington, DC.

Stevenson, C., G. Doherty, J. Barnett, O. T. Muldoon, and K. Trew. 2007. Adolescents' views of food and eating: Identifying barriers to healthy eating. J. Adolesc. 30:417-434. https://doi.org/10.1016/j .adolescence.2006.04.005. 
Sylvetsky, A. C., M. Greenberg, X. Zhao, and K. I. Rother. 2014. What parents think about giving nonnutritive sweeteners to their children: A pilot study. Int. J. Pediatr. 2014:819872. https://doi .org $/ 10.1155 / 2014 / 819872$.

Thompson, J. L., P. Gerard, and M. A. Drake. 2007. Chocolate milk and the Hispanic consumer. J. Food Sci. 72:S666-S675. https://doi .org/10.1111/j.1750-3841.2007.00559.x.

Trexler, M. L., and R. Sargent. 1993. Assessment of nutrition risk knowledge and its relationship to the dietary practices of adolescents. J. Nutr. Educ. 25:337-344.

Tuorila, H. 1987. Selection of milks with varying fat contents and related overall liking, attitudes, norms and intentions. Appetite 8:1-14. https://doi.org/10.1016/S0195-6663(87)80022-3.

USDA. 2019a. National School Lunch Program. Accessed Dec. 17, 2019. https://www.fns.usda.gov/nslp.

USDA. 2019b. School Breakfast Program. Accessed Dec. 17, 2019. https://www.fns.usda.gov/sbp/school-breakfast-program.

USDA. 2019c. Special Milk Program. Accessed Dec. 17, 2019. https:/ /www.fns.usda.gov/smp/special-milk-program.

USDHHS-USDA. 2015. 2015-2020 Dietary Guidelines for Americans. December 2015. 8th ed. Accessed Dec. 31, 2019. http://health .gov/dietaryguidelines/2015/guidelines/.

Valajoozi, M. R., and N. O. Zangi. 2016. A review on visual criteria of pure milk packaging for parents and their children (case study: Tehran, Iran). Br. Food J. 118:83-99. https://doi.org/10.1108/ BFJ-12-2014-0425.

Valkenburg, P. M., and M. Buijzen. 2005. Identifying determinants of young children's brand awareness: Television, parents, and peers. J. Appl. Dev. Psychol. 26:456-468. https://doi.org/10.1016/j .appdev.2005.04.004.

Ventura, A. K., and J. Worobey. 2013. Early influences on the development of food preferences. Curr. Biol. 23:R401-R408. https://doi .org/10.1016/j.cub.2013.02.037.

Wardle, J., M. Herrera, L. Cooke, and E. L. Gibson. 2003. Modifying children's food preferences: The effects of exposure and reward on acceptance of an unfamiliar vegetable. Eur. J. Clin. Nutr. 57:341348. https://doi.org/10.1038/sj.ejcn.1601541.

Watson, E. 2017. Fairlife ultra-filtered milk sales surged $79 \%$ in 2016; Core Power and Yup! to be brought under Fairlife brand umbrella. Accessed May 15, 2018. https://www.foodnavigator-usa.com/
Article/2017/09/12/fairlife-ultra-filtered-milk-sales-surged-79-in $-2016 \#$.

Weaver, C. M. 2010. Role of dairy beverages in the diet. Physiol. Behav. 100:63-66.

Wechsler, H., C. E. Basch, P. Zybert, and S. Shea. 1998. Promoting the selection of low-fat milk in elementary school cafeterias in an inner-city Latino community: Evaluation of an intervention. Am. J. Public Health 88:427-433. https://doi.org/10.2105/AJPH.88.3 .427.

Wilson, J. F. 2000. Lunch eating behavior of preschool children: Effects of age, gender, and type of beverage served. Physiol. Behav. 70:27-33. https://doi.org/10.1016/S0031-9384(00)00230-4.

Woodward, D. R., J. A. Boon, F. J. Cumming, P. J. Ball, H. M. Williams, and H. Hornsby. 1996. Adolescents' reported usage of selected foods in relation to their perceptions and social norms for those foods. Appetite 27:109-117. https://doi.org/10.1006/appe .1996 .0039 .

World Cancer Research Fund International. 2018. Diet, nutrition, physical activity and colorectal cancer. Continuous update project. World Cancer Research Fund International, London, UK.

Yoo, H. J., L. Machín, A. Arrúa, L. Antúnez, L. Vidal, A. Giménez, M. R. Curutchet, and G. Ares. 2017. Children and adolescents' attitudes towards sugar reduction in dairy products. Food Res. Int. 94:108-114. https://doi.org/10.1016/j.foodres.2017.02.005.

Zulewska, J., M. Newbold, and D. M. Barbano. 2009. Efficiency of serum proteins removal from skim milk with ceramic and polymeric membranes at $50^{\circ}$ C. J. Dairy Sci. 92:1361-1377. https://doi.org/ $10.3168 /$ jds.2008-1757.

Zygoura, P., T. Moyssiadi, A. Badeka, E. Kondyli, I. Savvaidis, and M. G. Kontominas. 2004. Shelf life of whole pasteurized milk in Greece: Effect of packaging material. Food Chem. 87:1-9. https:// doi.org/10.1016/j.foodchem.2003.10.009.

\section{ORCIDS}

Lauren R. Sipple @ https://orcid.org/0000-0001-8348-7886

David M. Barbano @

MaryAnne Drake @ https://orcid.org/0000-0002-4744-2493 